\title{
HEW Looks to its OWn
}

by our Washington Correspondent

As the defender of equal employment opportunities and the scourge of discrimination in higher education, the Department of Health, Education and Welfare has a special responsibility to keep its own house in order. That is one reason why Elliot L. Richardson, Secretary of HEW, in February last year set up a commission to help combat discrimination against women employed by HEW and in the programmes sponsored by the department. Called the Women's Action Program (WAP), the commission last week published findings which show good reason why the department should be as vigorous in its pursuit of justice in its own ranks as it is in its attempts to stamp out discrimination in the universities and elsewhere.

Based on investigations conducted between March and September last year, the WAP report documents a host of alleged discriminatory practices in HEW which add up to a situation in which women employees are crowded into the bottom grades, while men carry off the cream of the responsible and well paid jobs. In detail, women make up about 63 per cent of the department's employees - the highest percentage of all federal departments-but their average government service grade is 5.8. Men, on the other hand, enjoy an average grade of 10.9-a gap of five whole grades in a scale that only runs from 1 to 18 . And, to underline the difference, women hold only 14.4 per cent of the jobs in grades 13 to 18 while men occupy 85.6 per cent of the top leadership positions, and no woman has reached grade 18 in HEW.

Such figures are sufficient to make every feminist flush with anger and start to blame male chauvinism. But unfortunately the cause and solution to the situation are much more difficult to diagnose than the effects. For one thing, as the report makes plain, the situation in HEW is simply a reflexion of the distribution of men and women among lower and higher paid jobs in society at large. A prime cause is that secretaries and similar support staff tend to account for many of the lower graded jobs in government service, and secretaries usually tend to be women; and a prime obstacle is that for a significant change to take place, attitudes towards the employment of women (among men and women) must change.

With the caveat, however, the report suggests a string of changes that should be made by HEW to promote upward mobility of women employees and a more liberal attitude towards such reforms as day care facilities and maternity leave. A significant step had already been taken with the creation last spring of the Office of Upward Mobility-an office charged with helping all HEW employees to move upwards through the hierarchy by means of retraining, counselling and revamping of the personnel structure. Since women account for some 80 per cent of the seven lowest grades in HEW, this office will probably be of greatest benefit to them. One of the chief goals of the office, the WAP report suggests, should be to help qualified secretaries and staff assistants to move into administrative positions. Too often, their advancement is tied closely to that of their immediate boss.

As for the programmes and the research and education supported by HEW, the report has a few recommendations to make. For example, the National Institute of Mental Health should sponsor more research into the status of women in American society, the biological and social determinants of sex differences, children's sex and

Table 1 Median grade and distribution of men and women in agencies of HEW July 1971

\begin{tabular}{|c|c|c|c|c|c|c|c|}
\hline \multirow[b]{2}{*}{ Agency } & \multicolumn{3}{|c|}{ MEN } & \multicolumn{3}{|c|}{ WOMEN } & \multirow[b]{2}{*}{$\begin{array}{l}\text { differ- } \\
\text { ence in } \\
\text { median } \\
\text { grade }\end{array}$} \\
\hline & $\begin{array}{c}\text { Number in } \\
\text { Agency }\end{array}$ & $\begin{array}{l}\text { per cent } \\
\text { of a gency }\end{array}$ & $\begin{array}{c}\text { median } \\
\text { grade }\end{array}$ & $\begin{array}{c}\text { number in } \\
\text { agency }\end{array}$ & $\begin{array}{l}\text { per cent } \\
\text { of agency }\end{array}$ & $\begin{array}{c}\text { median } \\
\text { grade }\end{array}$ & \\
\hline SSA & 18,260 & 32.9 & 9.6 & 37,245 & 67.1 & 5.1 & 4.5 \\
\hline HSMHA & 6,627 & 34.5 & 10.3 & 12,580 & 65.5 & 5.8 & 4.5 \\
\hline NIH & 3.778 & 41.4 & 11.5 & 5.345 & 58.6 & 6.9 & 4.6 \\
\hline OS & 1,500 & 45.0 & 13.9 & 1,831 & 55.0 & 6.9 & 7.0 \\
\hline FDA & 2,911 & 62.1 & 12.3 & 1,775 & 37.9 & 6.1 & 6.2 \\
\hline $\mathrm{OE}$ & 1,500 & 45.0 & 13.9 & 1,831 & 55.0 & 6.9 & 7.0 \\
\hline SRS & 834 & 41.3 & 13.9 & 1,185 & 58.7 & 6.9 & 7.0 \\
\hline Tota & 36,443 & 36.9 & 10.9 & 62,288 & 63.1 & 5.8 & 5.1 \\
\hline \multicolumn{8}{|c|}{$\begin{array}{l}\text { SSA = Social Security Administration; HSMHA= Health Services and Mental Health } \\
\text { Administration; NIH=National Institutes of Health; OS=Office of the Secretary } \\
\text { FDA=Food and Drug Administration; OE= Office of Education ; SRS=Social and } \\
\text { Rehabilitation Service. }\end{array}$} \\
\hline
\end{tabular}

social role development, the psychological and social effects on a female rape victim and so on. The WAP report also points out that the Health Manpower Bureau of the National Institutes of Health has a potentially powerful role in overcoming sex discrimination in the health professions, and suggests that it should develop five and ten year goals to increase the number of women in medical and dental schools. Research into male contraceptives and other family planning methods are two obvious candidates for HEW sponsorship which the WAP report does not pass up.

Will the report do more than document the present situation before ending up in the waste baskets? There have, of course, already been suggestions that the Women's Action Program was set up chiefly as a convenient way of heading off criticism both from inside the department and from the universities which have been subject to action from HEW's Equal Employment Opportunities Office for their own discrimination. But Richardson has already asked the heads of HEW agencies to study the report and develop timetables to implement the recommendations pertinent to them. $\mathrm{He}$ also said at a press conference last week that he felt recommendations designed to increase opportunities for part time employment and day care facilities are most important.

\section{SOVIET UNION}

\section{Lerner's Battle}

by our Washington Correspondent

THE short detention and subsequent expulsion from the Soviet Union last week of Mr James H. Scheuer, a Congressman from New York, has brought to public attention the name of Professor Alexander Ya. Lerner, Scheuer's host the night he was detained by Soviet police. Lerner was one of the six or seven Soviet Jews visited privately by Scheuer during his visit to the USSR as part of a Congressional study group looking at educational institutions, and it was those visits that earned his expulsion on the grounds of improper conduct. Lerner is, however, perhaps the most important of the Soviet Jews visited by Scheuer, and his plight has received attention from scientists both in the USSR and in Western countries.

A distinguished scientist with an international reputation in cybernetics, control theory and systems theory, 